\title{
PENGARUH TATA KELOLA PERUSAHAAN DAN INTENSITAS MODAL TERHADAP PENGHINDARAN PAJAK
}

\author{
Dr. Sparta, ME., Ak., CA. ${ }^{1)}$ \\ Adhinda Ghinna Purnama ${ }^{2}$ \\ sparta@ibs.ac.id \\ STIE Indonesia Banking School
}

\begin{abstract}
ABSTRAK
Penelitian ini bertujuan untuk menguji hubungan antara tata kelola perusahaan yang terdiri dari Proporsi Dewan Komisaris Independen dan kepemilikan Institusional dan intensitas modal terhadap penghindaran pajak. Penelitian ini difokuskan pada perusahaan manufaktur yang terdaftar di Bursa Efek Indonesia (BEI) periode tahun 2017-2019. Penentuan jumlah sampel menggunakan metode purposive sampling, sehingga diperoleh sampel sebanyak 35 perusahaan manufaktur. Metode yang digunakan adalah regresi data panel dengan fixed effect Model (FEM). Hasil penelitian ini menunjukan bahwa proporsi dewan komisaris berpengaruh positif terhadap penghindaran pajak, intensitas modal tidak berpengaruh terhadap penghindaran pajak, serta kepemilikan institusional berpengaruh negatif terhadap penghindaran pajak.
\end{abstract}

Kata Kunci: tata kelola perusahaan; intensitas modal; penghindaran pajak.

\section{PENDAHULUAN}

Pajak memiliki peran yang sangat penting dalam pendapatan suatu negara. Di Indonesia sendiri pajak akan digunakan untuk pembiayaan dan pembangunan nasional. Seperti yang diatur dalam Undang-Undang Nomor 16 tahun 2009, yang mengatur tentang ketentuan umum dan prosedur perpajakan pada Pasal 1 ayat 1 yaitu, kontribusi wajib kepada negara oleh badan atau individu yang dipaksakan berdasarkan Undang-Undang, tanpa kompensasi langsung dan digunakan untuk kepentingan negara. Oleh karena itu, perkembangan perpajakan di Indonesia harus dikelola dengan baik.

Tabel 1.1. Pendapatan Negara Indonesia Tahun 2017-2019 (Dalam Miliar Rupiah)

\begin{tabular}{|c|c|c|c|}
\hline $\begin{array}{l}\text { Sumber Penerimaan } \\
2019\end{array}$ & 2017 & 018 & \\
\hline $\begin{array}{l}\text { Penerimaan Perpajakan } \\
1.546 .135\end{array}$ & Rp 1.343.530 & 18.791 & $\mathrm{Rp}$ \\
\hline $\begin{array}{cc}\text { Penerimaan Bukan Pajak } \\
\mathrm{Rp} & 10.654 \\
\end{array}$ & 18.510 & $\mathrm{Rp}$ & 20.922 \\
\hline $\begin{array}{l}\text { Jumlah/Total } \\
\text { Rp } 1.556 .789 \\
\end{array}$ & Rp 1.362.040 & $\mathrm{Rp}$ & 1.539 .713 \\
\hline
\end{tabular}


sesuai dengan kondisi yang sebenarnya. Pemerintah juga berupaya agar efektifitas pemungutan pajak di Indonesia terus mengalami peningkatan setiap tahun. Berdasarkan data yang saya peroleh berikut tabel efektifitas pemungutan pajak selama periode tahun 2017-2019.

Tabel 1.2. Efektifitas Pemungutan Pajak di Indonesia

\begin{tabular}{cccr}
\hline $\begin{array}{c}\text { Tahun } \\
\text { Pemungutan }\end{array}$ & Target & Realisasi & \multicolumn{2}{c}{ Efektifitas } \\
(persen) & (Triliun Rupiah) & (Triliun Rupiah) & Pajak \\
\hline 2017 & Rp. 1.473 & Rp. 1.344 & 91,23 \\
2018 & Rp. 1.618 & Rp. 1.285 & 93,86 \\
2019 & Rp. 1.786 & Rp. 1.546 & 87,00 \\
\hline
\end{tabular}

Sumber: www.kemenkeu.go.id

Namun, perusahaan sebagai wajib pajak memandang dari sisi yang berbeda. Bagi perusahaan pajak adalah biaya atau beban yang mengurangi laba bersih. Jika sebuah perusahaan menghasilkan keuntungan yang besar, pajak penghasilan yang dibayarkan ke kas negara juga besar. Oleh karena itu, perusahaan berusaha membayar pajak dengan sekecil mungkin agar memperleh laba yang maksimal.

Hal ini yang membuat perusahaan dalam upaya memperoleh laba yang maksimal melakukan berbagai cara seperti perencanaan pajak (tax planning) yang bertujuan agar perusahaan dapat membuat pajak yang akan dibayarnya tidak terlalu besar. Dalam usaha perusahaan meminimalisasi pajak yang akan dibayarkannya secara legal merupakan suatu bentuk tindakan penghindaran pajak (tax avoidance), sedangkan usaha dalam meminimalisasi pajak yang akan dibayarkan secara ilegal merupakan bentuk tindakan penggelapan pajak (tax evasion).

Maka dari itu, banyak perusahaan yang melakukan tindakan penghindaran pajak (tax avoidance) untuk memaksimalkan laba yang didapat dengan tetap memperhatikan dan mematuhi peraturan yang ada. Sehingga didalam sebuah perusahaan perlu adanya tata kelola perusahaan atau corporate governance $(C G)$ yang diciptakan untuk mengawasi perusahaan dalam usahanya untuk meminimalisasikan pajak yang akan dibayarnya agar mampu berjalan dibawah hukum yang berlaku. Tata kelola perusahaan $(C G)$ memastikan bahwa tata kelola perusahaan dalam perpajakan tetap berada dalam lingkup penghindaran pajak (tax avoidance) yang bersifat bukan penggelapan pajak (tax evasion).

Di dalam penerapan tata kelola perusahaan $(C G)$ dapat dilihat pengaruhnya dengan mekanisme penggunaan proksi, yaitu ukuran perusahaan (company size), proporsi dewan komisaris (the proportion of board commissioners), kepemilikan institusional (institutional ownership) terhadap tindakan penghindaran pajak (tax avoidance) yang dilakukan oleh perusahaan.

Menurut (Kurniasih \& Sari, 2013) ukuran perusahaan (company size) menunjukkan kestabilan dan kemampuan perusahaan untuk melakukan aktivitas ekonominya. Semakin besar ukuran suatu perusahaan maka semakin menjadi pusat perhatian dari pemerintah dan akan menimbulkan kecenderungan bagi para manajer perusahaan untuk berlaku patuh (compliances) atau agresif (tax avoidance) dalam perpajakan. Semakin besar ukuran perusahaan (company size), maka perusahaan akan lebih mempertimbangkan risiko dalam hal mengelola beban pajaknya (Darmawan \& Sukartha, 2014). Dalam hasil penelitian yang dilakukan sebelumnya oleh (Kurniasih \& Sari, 2013) menyatakan bahwa ukuran perusahaan (company size) berpengaruh signifikan terhadap penghindaran pajak (tax avoidance) perusahaan.

Jurnal Ilmiah Akuntansi dan Ekonomi Volume. 6 Nomor. 2, Agustus 2021 Hal. 39 
Penerapan dari tata kelola perusahaan $(C G)$ juga dilatar belakangi oleh masalah struktur kepemilikan. Yang dalam penelitian ini, struktur kepemilikian perusahaan akan difokuskan pada struktur kepemilikan institusional (institutional ownership). Peran dari kepemilikan institusional (institutional ownership) sangat penting bagi perusahaan dalam mengawasi kinerja manajemen yang lebih optimal. Sehingga, dengan adanya kepemilikan institusional (institutional ownership) maka akan ada kontrol yang lebih baik. Menurut (Okrayanti, Nuaraina \& Utomo, 2017) Kepemilikan institusional (institutional ownersip) memiliki pengaruh signifikan besar terhadap investasi pendanaan yang dilakukan termasuk juga investasi saham. Investor institusional dapat mengurangi biaya hutang dalam mengurangi masalah keagenan, sehingga dapat mengurangi peluang dari terjadinya penghindaran pajak (tax avoidance).

Dewan komisaris (board of commissioners) terdiri dari komisaris independen dan komisaris non-independen. Komisaris independen bukanlah entitas afiliasi, sedangkan komisaris non-ndependen adalah entitas afiliasi (Fadhilah, 2014). Afiliasi adalah pihak yang memiliki hubungan bisnis dan kekerabatan yang dapat mengendalikan pemegang saham, direktur, komisaris, dan perusahaan itu sendiri (KNKG, 2006).

Tata kelola perusahaan $(C G)$ telah dibentuk atas permintaan dalam manajemen pajak yang dimana salah satunya adalah meliputi transparansi yang merupakan keterbukaan dalam melaksanakan proses pengambilan keputusan dan keterbukaan mengemukakan informasi materil dan relevan mengenai perusahaan. Selain tata kelola perusahaan $(C G)$, ukuran perusahaan (company size), proporsi dewan komisaris (the proportion of board commissioners), dan kepemilikan institusional (institutional ownership) banyak faktor variabel lain yang mempengaruhi perusahaan untuk melakukan penghindaran pajak (tax avoidance), yaitu intensitas modal (capital intensity), leverage.

Menurut (Dharma \& Noviari, 2017) intensitas modal (Capital Intensity) menjelaskan seberapa besar perusahaan menginvestasikan asetnya dalam bentuk aset tetap dan inventaris. Perusahaan yang memiliki aset tetap tinggi memiliki beban pajak yang rendah dibandingkan perusahaan yang memiliki aset tetap rendah. Selain hal di atas, terdapat indikasi bahwa penghindaran pajak perusahaan dapat dilihat dari kebijakan pembiayaan perusahaan. Salah satu kebijakan pembiayaan adalah kebijakan leverage. Menurut (Darmawan \& Sukharta, 2014) leverage merupakan rasio yang menunjukan besarnya utang perusahaan untuk membiayai oktivitas operasi perusahaan tersebut

Penghindaran pajak (tax avoidance) dapat terjadi pada beberapa kasus di dalam perusahaan. Seperti yang terjadi pada fenomena belakangan ini yaitu dugaan penghindaran pajak yang dilakukan oleh PT Adaro Energy Tbk pada tahun 2019. PT Adaro Energy Tbk dalam menghindari kewajiban pajak perusahaan melaukan skema transfer pricing melalui anak perusahaan yang berada di Singapura. Pada laporan investigasi yang diterbitkan oleh Global Witness, PT Adaro Energy Tbk diindikasi melarikan pendapatan dan labanya ke luar negeri sehingga dapat menekan pajak yang dibayarkan kepada pemerintah. Menurut Global Witness, cara ini dilakukan dengan menjual batu bara dengan harga murah ke anak perusahaan Adaro di Singapura, Coaltrade Services International untuk dijual lagi dengan harga tinggi. Melalui perusahaan itu, Global Witness menemukan potensi pembayaran pajak yang lebih rendah dari seharusnya dengan nilai 125 juta dolar AS kepada 
pemerintah Indonesia. Di samping itu, Global Witness juga menunjuk peran negara suaka pajak yang memungkinkan Adaro mengurangi tagihan pajaknya senilai 14 juta dolar AS per tahun (Sumber: www.tirto.id).

Penelitian terkait intensitas modal (capital intensity) terhadap penghindaran pajak (tax avoidance) telah dilakukan diantaranya oleh (Budianti \& Curry, 2018) dan (Muzakki \& Darsono, 2015) yang menemukan bahwa intensitas modal (capital intensity) memiliki pengaruh negatif terhadap penghindaran pajak (tax avoidance), Sementara penelitian yang dilakukan oleh (Irianto, Sudibyo, \& Wafirli, 2017) menemukan bahwa intensitas modal (capital intensity) berpengaruh positif terhadap penghindaran pajak (tax avoidance). Penelitian terkait dengan tata kelola perusahaan $(C G)$ terhadap penghindaran pajak (tax avoidance) telah dilakukan sebelumnya diantaranya (Okrayanti, Nuaraina, \& utomo, 2017) menemukan bahwa tata kelola perusahaan $(C G)$ berpengaruh positif pada penghindaran pajak (tax avoidance). Hal ini bertolak belakang dengan penelitian yang dilakukan oleh (Armstrong et al., 2015) yang menyatakan bahwa tata kelola perusahaan $(C G)$ berpengaruh negatif terhadap penghindaran pajak (tax avoidance).

Berdasarkan latar belakang masalah diatas, maka perumusan masalah yang dapat dikemukakan adalah sebagai berikut: 1) Apakah tata kelola perusahaan berpengaruh negatif terhadap penghindaran pajak?; 2) Apakah intensitas modal berpengaruh positif terhadap penghindaran pajak.

\section{LANDASAN TEORI}

\section{Agency Theory}

Menurut (Jensen \& Meckling, 1976) hubungan keagenan merupakan suatu kontrak dimana satu atau lebih orang (principal) memerintah orang lain (agent) untuk melakukan suatu jasa atas nama principal serta memberi wewenang kepada agent membuat keputusan yang terbaik bagi principal. Agar hubungan kontraktual ini dapat berjalan dengan lancar, pemilik (principal) akan mendelegasikan otoritas pembuatan keputusan kepada manajer (agent). Teori keagenan menyatakan bahwa ada konflik kepentingan antara pemilik (principal) dan manajer (agent) (Arianandini \& Ramantha, 2018). Jika pemilik (principal) dan manajer (agent) bertindak untuk memaksimalkan kepentingannya masing-masing, ada alasan untuk percaya bahwa manajer (agent) tidak akan selalu bertindak demi kepentingan pemilik (principal) (Jensen \& Meckling, 1976). Hal tersebut dapat menimbulkan terjadinya masalah keagenan. Masalah keagenan timbul sehubungan dengan penghindaran pajak jika pemilik (principal) dan manajer (agent) mengevaluasi biaya dan manfaat penghindaran pajak secara berbeda (Arianandini \& Ramantha, 2018). Pengaruh dalam melakukan tindakan penghindaran pajak adalah pengurangan beban pajak yang harus dibayarkan oleh perusahaan. Dengan hal ini, laba perusahaan dapat mengalami peningkatan, sehingga manajer (agent) bisa memperoleh insentif yang lebih tinggi.

\section{Tata Kelola Perusahaan}

Tata kelola perusahaan didefinisikan sebagai efektivitas mekanisme yang bertujuan meminimumkan konflik keagenan, dengan penekanan khusus pada mekanisme legal yang mencegah dilakukan nya pengambilalihan atas pemegang saham minoritas (Kurniasih \& Sari, 2013). Tata kelola perusahan telah dianggap sebagai alat yang penting dalam menilai kesehatan perusahaan, terutama kondisi 
kesulitan keuangan. Dalam memaksimalkan tingkat kinerja, perusahaan dapat menerapkan tata kelola perusahaan yang dapat menjadi pedoman manajer dalam mencapai tujuan yang diharapkan oleh pemegang saham yaitu meningkatkan nilai perusahaan (Jensen \& Meckling, 1976). Dapat disimpulkan bahwa tata kelola perusahaan ini adalah faktor penting dalam pengendalian perusahaan, sehingga kegiatan di dalam perusahaan dapat dilakukan secara efektif sesuai dengan kebijakan dan peraturan yang berlaku. Setiap perusahaan harus memastikan bahwa asas tata kelola perusahaan yang baik diterapkan untuk semua aspek bisnis dan semua tingkat perusahaan. Asas tata kelola perusahaan yang baik meliputi transparansi, akuntabilitas, responsibilitas, independensi serta kewajaran dan kesetaraan yang diperlukan untuk mencapai kesinambungan usaha perusahaan dengan memperhatikan para pemangku kepentingan (KNKG, 2011). Dalam penerapan tata kelola perusahaan dapat dilihat pengaruhnya dengan mekanisme penggunaan proksi, yaitu kompensasi eksekutif, karakter eksekutif, ukuran perusahaan, kepemilikan institusional, proporsi dewan komisaris, komite audit dan kualitas audit.

\section{Intensitas Modal}

Intensitas Modal (Capital Intensity) menggambarkan seberapa besar perusahaan menginvestasikan asetnya dalam bentuk aset tetap dan persediaan (Muzakki \& darsono, 2015). Berdasarkan teori keagenan yang menyatakan adanya asimetris hubungan antara principal dengan agent (Jensen \& Meckling, 1976). Pemerintah (principal) ingin mendapatkan pendapatan yang tinggi melalu pajak, sedangkan manajer (agent) ingin meminimalkan pembayaran beban pajak dari intensitas modal. Manajer akan melakukan investasi terhadap aset tetap perusahaan untuk mendapatkan keuntungan berupa biaya depresiasi yang berguna untuk meminimalkan beban pajak. Sehingga kinerja perusahaan akan meningkat karena adanya pengurangan beban pajak serta kompensasi kinerja manajer yang diinginkan akan tercapai (Dharma \& Noviari, 2017). Hal ini menunjukan bahwa perusahaan yang memiliki aset tetap tinggi akan memiliki tarif efektifitas pajak yang rendah.

\section{Pengembangan Hipotesis}

Agency theory menjelaskan jika kedua belah pihak memaksimalkan kepentingannya individu, ada alasan untuk percaya bahwa manajer (agent) tidak akan selalu bertindak demi kepentingan pemilik (principal) (Jensen \& Meckling, 1976). Dimana konflik kepentingan ini dapat diminimalisir oleh kesejajaran mekanisme kepentingan ekternal dan internal yang dikenal dengan tata kelola perusahaan.

Dalam penelitian ini tata kelola perusahaan diproksikan menggunakan dua pengukuran, yaitu:

a. Proporsi Dewan Komisaris

Berdasarkan teori keagenan (Jesen \& Meckling, 1976) yang menjelaskan adanya perbedaan kepentingan antara manajemen perusahaan dengan dewan komisaris, dimana manajemen perusahaan dalam melakukan kegiatan operasional perusahaan ingin meningkatkan laba perusahaan dengan cara menekankan beban perusahaan melalui pajak yang mengakibatkan adanya kecurangan dalam pelaporan keuangan. Sedangkan dewan komisaris dapat melaksanakan fungsi monitoring dalam mendukung corporate governance yang baik dan menjadikan laporan keuangan lebih objektif (Kurniasih \& Sari, 
2013). Hal ini dilakukan dengan cara mendorong anggota dewan komisaris yang lain agar melakukan tugasnya, seperti pengawasan dan pemberian nasihat kepada para direktur secara efektif serta dapat memberikan keuntungan lebih untuk memastikan tidak adanya kecurangan manajemen perusahaan dalam penghindaran pajak yang bertujuan untuk memperoleh keuntungan individu. Menurut (Kurniasih \& Sari, 2013) proporsi dewan komisaris berpengaruh negatif terhadap penghindaran pajak. Yang artinya semakin tinggi tingkat proporsi dewan komisaris maka semakin rendah indikasi penghindaran pajak yang dilakukan oleh perusahaan. Berdasarkan uraian diatas, maka hipotesis dalam penelitian ini dirumuskan sebagai berikut:

\section{$\mathrm{H}_{1 \mathrm{a}}$ : Proporsi dewan komisaris berpengaruh negatif terhadap penghindaran pajak.}

b. Kepemilikan Institusional

Kepemilikan institusional merupakan salah satu cara yang dapat mengurangi konflik agensi. Dengan adanya tanggung jawab perusahaan kepada pemegang saham, maka pemilik institusional memiliki insentif untuk memastikan bahwa manajemen dalam melaksanakan kegiatan operasional perusahaan mengambil keputusan secara baik dan tepat. Menurut penelitian (Arianandini \& Ramantha, 2018) yang menyatakan bahwa kepemilikan instituasional. Berpengaruh negatif terhadap penghindaran pajak. Yang artinya keberadaan struktur kepemilikan instituasional terhadap manajemen perusahaan tersebut terindikasi adanya tekanan dari pihak instituasional dalam melakukan kebijakan pajak agresif untuk memperoleh laba yang maksimal bagi investor. Semakin tinggi tingkat kepemilikan institusional maka semakin rendah tingkat penghindaran pajak yang dilakukan oleh perusahaan (Okrayanti, Nuaraina \& Utomo, 2017). Berdasarkan uraian diatas, maka hipotesis dalam penelitian ini dirumuskan sebagai berikut:

\section{H1b: Kepemilikan instituasional berpengaruh negatif terhadap penghindaran pajak.}

c. Intensitas Modal adalah aktivitas investasi dimana pada pelaksanaannya dilakukan oleh perusahaan dalam bentuk aset tetap. Dibandingkan dengan perusahaan lain, perusahaan dengan modal yang intensif memiliki peluang lebih besar untuk strategi penghindaran pajak. Berdasarkan teori keagenan dimana manajer untuk memenuhi kepentingan individu dalam mencapai kompensasi kinerja yang maksimal, manajer melakukan pengurangan beban pajak perusahaan agar mendapatkan laba yang tinggi. Pengurangan beban pajak perusahaan yang dibayarkan akan melakukan penyusutan aset tetap dan dibebankan sebagai pengurang laba. Hal ini menunjukan bahwa perusahaan yang memiliki aset tetap banyak, tarif efektif pajak yang dibayarkan cenderung rendah. Penelitian (Dharma \& Noviari, 2017), (Dharma \& Noviari, 2017), dan (Irianto, Sudibyo, \& Wafirli, 2017) menyatakan bahwa terdapat hubungan positif antara insensitas modal (capital intensity) dan penghindaran pajak (tax avoidance). Yang artinya semakin tinggi intensitas modal (capital intensity) suatu perusahaan, maka semakin tinggi indikasi dalam melakukan penghindaran pajak (tax avoidance). Berdasarkan uraian diatas, maka hipotesis dalam penelitian ini dirumuskan sebagai berikut:

\section{H2: Intensitas modal berpengaruh positif terdahap penghindaran pajak.}




\section{METODOLOGI PENELITIAN}

Objek dalam penelitian ini adalah perusahaan industri manufaktur yang terdaftar di Bursa Efek Indonesia pada periode tahun 2017-2019 secara berturutturut, perusahan industri manufaktur yang mempublikasikan laporan keuangan menggunakan tahun buku yang berakhir pada 31 Desember, perusahaan industri manufaktur yang mempublikasikan laporan keuangan dalam satu satuan mata uang rupiah (Rp) dan telah diaudi, perusahaan industri manufaktur yang memiliki nilai laba positif agar tidak menyebabkan penyimpangan pada nilai CETR, laporan keuangan yang dipublikasikan terdapat data- data yang lengkap. Sumber data penelitian diperoleh dari situs resmi Bursa Efek Indonesia www.idx.co.id serta website dari masing-masing perusahaan. Penelitian ini menggunakan variabel independen dan variabel kontrol, serta menggunakan 35 sampel perusahaan industri manufaktur dimana daftar perusahaan yang dijadikan sampel terlampir dalam tabel 3.1. dalam lampiran penelitian ini, yang mana model regresi penelitian ini adalah sebagai berikut:

$$
\begin{aligned}
\text { CETR } \mathrm{i}, \mathrm{t}= & \beta 0+\beta 1 P D K i, \mathrm{t}+\beta 2 \mathrm{KI} i, \mathrm{t}+\beta 3 \mathrm{CI} i, \mathrm{t}+\beta 4 \text { SIZE } i, \mathrm{t} \\
& +\beta \text { SLEV } i, \mathrm{t}+\varepsilon i, \mathrm{t}
\end{aligned}
$$

Dimana operasionalisasi variabel dijelaskan dalam tabel 3.2. dalam lampiran penelitian ini.

\section{ANALISIS DAN PEMBAHASAN}

Berdasarkan hasil statistik deskriptif pada tabel 3.3. dalam lampiran, variabel penghindaran pajak memiliki rata-rata sebesar $-3,50 \%$ dalam kurun waktu 2017-2019, dengan nilai maksimum sebesar $-5,30 \%$ yang terdapat pada PT Indo Acidatama Tbk tahun 2017 sedangkan nilai minimum sebesar -14,22\% yang terdapat pada PT Trisula International Tbk tahun 2017. Variabel proporsi dewan komisaris memiliki rata-rata sebesar 43,64\% dalam kurun waktu 2017-2019 dengan nilai maksimum sebesar $80 \%$ yang terdapat pada PT Unilever Indonesia Tbk tahun 2017-2019 sedangkan nilai minimum sebesar 30\% yang terdapat pada PT Astra International Tbk tahun 2018 dan 2019. Variabel kepemilikan institusional memiliki rata-rata sebesar 78,79\% dalam kurun waktu 2017-2019, dengan nilai maksimum sebesar 99,95\% yang terdapat pada PT Fajar Surya Wisesa Tbk tahun 2019 sedangkan nilai minimum sebesar 36,30\% yang terdapat PT Ultra Jaya Milk Industry Tbk tahun 2018. Variabel intensitas modal memiliki rata-rata 94,89\% dalam kurun waktu 2017-2019 dengan nilai maksimum sebesar 235,62\% yang terdapat pada PT Waskita Beton Precast Tbk tahun 2019 nilai minimum sebesar 15,39\% yang terdapat PT Kino Indonesia Tbk tahun 2019. Variabel kontrol pertama yaitu ukuran perusahaan memiliki rata-rata sebesar 4,845,738 dalam kurun waktu 2017-2019 dengan nilai maksimum sebesar 351,957,318 Juta yang terdapat pada PT Astra International Tbk tahun 2019 sedangkan nilai minimum sebesar 159,567 Juta yang terdapat pada PT Pyridam Farma Tbk tahun 2017. Variabel kontrol kedua yaitu leverage memiliki rata-rata sebesar 46,62\% dalam kurun waktu 2017-2019 dengan nilai maksimum sebesar $697,45 \%$ yang terdapat pada PT Waskita Beton Precast Tbk tahun 2019 sedangkan nilai minimum sebesar 8,31\% yang terdapat pada PT Industri Jamu Dan Farmasi Sido Muncul Tbk tahun 2017.

Berdasarkan analisa data panel pada tabel 3.4. dan 3.5. dalam lampiran, fixed effect model yang baik digunakan untuk penelitian ini. Untuk uji asumsi klasik dalam lampiran, data penelitian terdistribusi secara normal sesuai grafik 3.1. 
kemudian untuk tabel 3.6., 3.7., dan 3.8. menunjukkan bahwa penelitian terbebas dari multikolinearitas, heteroskedastisitas, dan autokorelasi.

Berdasrkan hasil analisis persamaan regresi dalam tabel 3.9. dalam lampiran penelitian ini, diperoleh persemaan regresi sebagai berikut:

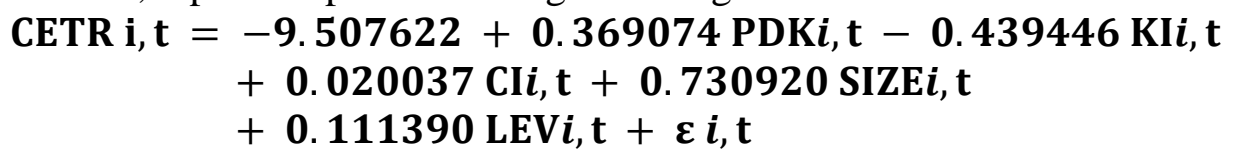

Hasil penelitian tabel 3.9. dalam lampiran menunjukkan bahwa variabel proporsi dewan komisaris yang merupakan proksi dari tata kelola perusahaan berpengaruh positif dan signifikan terhadap penghindaran pajak, sehingga menolak hipotesis pertama bagian a. Indikasi hasil yang positif menunjukan bahwa ketika tingkat proporsi dewan komisaris bertambah maka akan menyebabkan peningkatan pada penghindaran pajak. (Pattiasina et al., 2019) dalam penelitiannya menyatakan bahwa dewan komisaris merupakan inti dari tata kelola perusahaan yang bertugas untuk mengawasi pengelolaan perusahaan yang dilakukan oleh manajemen. Selain itu dewan komisaris akan diberikan wewenang untuk memberikan persetujuan atas setiap perbuatan yang akan dilakukan oleh direksi (Okrayanti, Nuraina, \& Utomo, 2017). Besarnya jumlah proporsi dewan komisaris akan mengakibatkan berkurangnya tingkat pengendalian pada setiap individu dewan komisaris atas pengawasan dan persetujuan jalannya operasional perusahaan. Hal ini memberikan kesempatan bagi manajer untuk melakukan aktivitas manipulasi laba yang nantinya akan menguntungkan perusahaan dalam hal perpajakan (Okrayanti, Nuraina, \& Utomo, 2017). Berkaitan dengan teori agensi (Jasen \& Meckling, 1976) yang menunjukan adanya kepentingan manajer dalam memaksimalkan kompensasi kinerja, memungkinkan manajer melakukan penghindaran pajak untuk menghasilkan laba perusahaan yang maksimal. Kurangnya pengawasan dewan komisaris terhadap kegiatan operasional perusahaan mendukung timbulnya peningkatan penghindaran pajak yang terjadi, hal ini dikarenakan banyaknya campur tangan setiap individu dalam penentuan keputusan yang terjadi akibat banyaknya jumlah proporsi dewan komisaris. Namun, hubungan proporsi dewan komisaris terhadap penghindaran pajak dapat berubah tergantung pada karakteristik perusahan itu sendiri. Sebagaimana yang dijelaskan dalam penelitian (Kurniasih \& Sari, 2013) yang menjelaskan bahwa proporsi dewan komisaris memberikan hubungan yang negatif pada penghindaran pajak dengan cara memaksimalkan fungsi pengawasan untuk mendukung pengelolaan perusahaan yang baik dan menjadikan laporan keuangan lebih objektif.

Pada variabel kepemilikan institusional yang merupakan proksi dari tata kelola perusahaan menunjukkan hasil negatif dan signifikan terhadap penghindaran pajak, sehingga menerima hipotesis pertama bagian b. Indikasi hasil yang diperoleh menunjukkan bahwa menurut (Okrayanti, Nuaraina \& Utomo, 2017) menyatakan semakin tinggi tingkat kepemilikan institusional semakin rendah tingkat penghindaran pajak yang dilakukan oleh perusahaan. Hal ini didukung oleh hasil penelitian (Arianandini \& Ramantha, 2018) yang menyatakan bahwa perusahaan dengan kepemilikan institusional yang besar lebih memungkinkan untuk memperkirakan dan mengeluarkan sesuatu yang lebih akurat. Kondisi ini didukung oleh pihak instituasional yang ikut serta secara langsung dalam pengambilan keputusan terhadap kegiatan operasional perusahaan sehingga kinerja perusahaan 
lebih efektif dan efesien. Berkaitan dengan teori agensi (Jasen \& Meckling, 1976) yang menyatakan bahwa terdapat pemisah anatara pemilik dengan manajer. Dimana manajer bertindak sebagai pelaksana kegiatan operasional perusahaan dan peranan kepemilikan institusional sebagai pengendali terhadap pengambilan keputusan secara langsung. Dengan hal tersebut pemilik dapat meminimalisir potensi penghindaran pajak perusahaan yang dilakukan oleh manajer. Oleh sebab itu, perusahaan harus memaksimalkan tugas setiap dewan komisaris dalam mengawasi jalannya operasional perusahaan agar tidak terjadinya kecurangan pada pelaporan keunagan perusahaan. Serta bagi regulator pemerintah sebaiknya menetapkan peraturan mengenai kewajiban jumlah komisaris independent dalam suatu perusahaan diatas $50 \%$ dari jumlah dewan komisaris agar dapat lebih seimbang dan konsisten dalam pengambilan keputusan.

Pada variabel intensitas modal menunjukkan hasil positif namun tidak signifikan terhadap penghindaran pajak, sehingga menolak hipotesis kedua. Indikasih hasil penelitian ini tidak menemukan adanya pengaruh jumlah aset tetap yang besar terhadap penghindaran pajak yang dilakukan perusahaan. (Wiguna \& Jati, 2017) menyatakan tidak adanya pengaruh dari jumlah aset tetap yang dimiliki perusahaan diakibatkan oleh perusahaan dengan jumlah aset tetap yang besar memang menggunakan aset tetap tersebut untuk kepentingan perusahaan, yaitu menunjang kegiatan operasional perusahaan yang digunakan untuk penyediaan barang dan jasa. Hal ini menunjukan bahwa perusahaan dengan aset tetap yang besar memang menggunakan aset tetap tersebut untuk kepentingan perusahaan, yaitu menunjang kegiatan operasional perusahaan bukan untuk menghindari pajak serta perusahaan besar biasanya aset tetap yang digunakan sudah habis masa manfaatnya. Dalam penelitian ini aset tetap tidak mampu mempengaruhi kecenderungan perusahaan untuk melakukan penghindaran pajak. Walaupun hasil yang diperoleh tidak signifikan namun pemerintah diharapkan tetap tegas terhadap perusahaan dalam pelaporan aset tetapnya agar perusahaan dapat memenuhi kewajibannya dalam hal pembayaran pajak.

Pada variabel ukuran perusahaan yang merupakan variabel kontrol menunjukkan hasil positif dan signifikan terhadap penghindaran pajak. Indikasi hasil yang diperoleh (Darmawan \& Sukartha, 2014) dalam penelitian menunjukan bahwa semakin besar perusahaan, maka semakin besar sumber daya yang dimiliki perusahaan dalam mengelola beban pajaknya. Perusahaan besar akan memiliki perhatian khusus dari pemerintah yang terkait dengan aset perusahaan, tingkat penjualan dan laba yang akan dipeoleh. Sehingga perusahaan besar dapat menarik perhatian wajib pajak dalam memenuhi kewajiban perpajakannya. Berdasarkan teori agensi (Jesen \& Meckling, 1976) yang menjelaskan hubungan anatara manajer dan pemerintah yang memiliki perbedaan kepentingan. Dimana manajer dalam memaksimalkan kompensasi kinerja, akan menekan beban pajak yang dikeluarkan oleh perusahaan guna memaksimalkan kinerja dan pendapatan laba perusahaan.

Pada variabel leverage yang merupakan variabel kontrol menunjukkan hasil positif dan signifikan terhadap penghindaran pajak. Indikasi hasil yang diperoleh (Kurniasih \& Sari, 201) dalam penelitiannnya menunjukan bahwa semakin tinggi nilai leverage maka semakin tinggi pula jumlah pendanaan hutang pihak ketiga yang digunakan oleh perusahaan, maka semakin tinggi pula biaya bunga yang keluar dari utang. Dimana perusahaan yang memiliki hutang yang tinggi akan mendapatkan intensif yang berupa potongan atas bunga pinjaman yang sesuai 
dengan pasal 6 ayat (1A) UU No. 36 tahun 2008 menyatakan bahwa bunga hutang dapat mengurangi perhitungan pajak perusahaan. Dengan demikian peraturan tersebut dapat digunakan perusahaan sebagai celah untuk melakukan penghindaran pajak dengan cara menambah hutang perusahaan untuk memperoleh intensif pajak.

\section{KESIMPULAN DAN REKOMENDASI}

Kesimpulan yang diperoleh dari penelitian ini antara lain sebagai berikut:

1. Proporsi dewan komisaris, sebagai salah satu proksi untuk mengukur tata kelola perusahaan berpengaruh positif terhadap penghindaran pajak. Ini artinya semakin besar jumlah dewan komisaris maka semakin tinggi penghindaran pajaknya sehingga jumlah pajak yang dibayarkan semakin sedikit;

2. Kepemilikan institusional, sebagai proksi lainnya untuk mengukur tata kelola perusahaan berpengaruh positif terhadap penghindaran pajak. Semakin tinggi kepemilikan institusional maka semakin tinggi terhadap penghindaran pajak;

3. Intensitas modal tidak berpengaruh terhadap penghindaran pajak. Ini artinya intesitas modal naik atau turun tidak berdampak pada upaya untuk penghindaran pajak.

Penelitian ini memiliki keterbatasan dan saran yang diharapkan dapat diperbaiki pada penelitian selanjutnya, diantaranya:

1. Penelitian ini hanya menggunakan 2 (dua) variabel independen yaitu tata kelola perusahaan dan intensitas modal serta 2 (dua) variabel kontrol yaitu ukuran perusahaan dan leverage. Diharapkan pada penelitian selanjutnya dapat mengembangkan dan memodifikasi kembali penelitian terdahulu dengan menambah variabel independen seperti profitabilitas, Corporate Social Responsibility, likuiditas, karakteristik perusahaan, dan variabel lainnya.

2. Objek pada penelitian ini terbatas pada perusahaan industri manufaktur yang terdaftar di Bursa Efek Indonesia Periode tahun 2017-2019. Sehingga hasil penelitian tidak dapat digunakan pada industri lain. Diharapkan pada penelitian selanjutnya dapat memeperluas sektor perusahaan di Indonesia serta dapat memperpanjang periode yang digunakan pada penelitian agar dapat mendapatkan hasil yang baik dan bisa digeneralisasi.

3. Pengukuran penghindaran pajak pada penelitian ini hanya menggunakan CETR sebagai alat ukur. Diharapkan pada penelitian selanjutnya dapat mengembangkan dan memodifikasi kembali penelitian terdahulu dengan menambahkan alat ukur pada variabel penghindaran pajak seperti ETR dan lainnya. 


\section{DAFTAR PUSTAKA}

Agusti, W. Y. (2013). Pengaruh Profitabilitas, Leverage, dan Corporate Governance (Studi Empiris Pada Perusahaan Manufaktur yang Terdaftar di BEI tahu 20092012. Jurnal Simposium Nasional Akuntansi, 4(2), 1-32.

Arianandini, P. W., \& Ramantha, I. W. (2018). Pengaruh Profitabilitas, Leverage, dan Kepemilikan Institusional Pada Tax Avoidance. E-Jurnal Akuntansi, 22, 2088. https://doi.org/10.24843/eja.2018.v22.i03.p17

Armstrong, C. S., Blouin, J. L., Jagolinzer, A. D., \& Larcker, D. F. (2015). Corporate governance, incentives, and tax avoidance. Journal of Accounting and Economics, 60(1), 1-17. https://doi.org/10.1016/j.jacceco.2015.02.003

Budhi, N., \& Dharma, S. (2017). Pengaruh Corporate Social Responsibility Dan Capital Intensity Terhadap Tax Avoidance. E-Jurnal Akuntansi, 18, 529-556.

Budianti, S., \& Curry, K. (2018). Pengaruh Profitabilitas, likuiditas, dan Capital Intensity Terhadap Penghindaran Pajak (Tax Avoidance). Prosiding Seminar Nasional Cendekiawan 4, Jakarta.

Darmawan, I., \& Sukartha, I. (2014). Pengaruh Penerapan Corporate Governance, Leverage, Roa, Dan Ukuran Perusahaan Pada Penghindaran Pajak. E-Jurnal Akuntansi, 9(1), 143-161.

Fadhilah, R. (2014). Pengaruh Good Corporate Governance Terhadap Tax Avoidance. Jurnal Universitas Negeri Padang, 2(1), 1-22. http://ejournal.unp.ac.id/students/index.php/akt/article/view/908/658

Ghozali, I., \& Ratmono, D. (2013). ANALISIS MULTIVARIAT DAN EKONOMETRIKA: TEORI, KONSEP, DAN APLIKASI DENGAN EVIEWS 8. Badan Penerbit Universitas Diponegoro, Semarang.

Gujarati, D. N. (2009). Basic Econometrics (Fifth). The Mcgraw-Hill Companies.

Irianto, Dr. B. S., \& S.Ak, A. W. (2017). The Influence of Profitability, Leverage, Firm Size and Capital Intensity Towards Tax Avoidance. International Journal of Accounting and Taxation, 5(2), 33-41. https://doi.org/10.15640/ijat.v5n2a3

James Kessler. (2004). Tax avoidance Purpose and Section 741 of the Taxes Act 1988. British Tax Review.

Jensen, M. C., \& Meckling, W. H. (1976). THEORY OF THE FIRM: MANAGERIAL BEHAVIOR, AGENCY COSTS AND OWNERSHIP STRUCTURE. Journal of Financial Economics, 3, 305-360. https://doi.org/10.1016/0304-405X(76)90026-X

Kementerian Keuangan Republik Indonesia. (2019). Laporan keuangan 2019. Diakses di https://www.kemenkeu.go.id/media/15865/laporan-keuangan2019.pdf

Kementerian Keuangan Republik Indonesia. (2018). Laporan Keungan 2018. Diakses di https://www.kemenkeu.go.id/media/12773/laporan-keuangan2018.pdf.

KNKG. (2011). Pedoman Good Corporate Governance Perusahaan Konsultan Aktuaria Indonesia. Jakarta. Retrieved from http://www.knkgindonesia.org/dokumen/Pedoman-GCG-Konsultan-Aktuaria.pdf

Kuncoro, M., (2009). Metode Riset untuk Bisnis \& Ekonomi, Edisi Ketiga, Erlangga, Jakarta. 
Kurniasih, T., \& Ratna Sari, M. (2013). Pengaruh Return on Assets, Leverage, Corporate Governance, Ukuran Perusahaan Dan Kompensasi Rugi Fiskal Pada Tax Avoidance. Buletin Studi Ekonomi, 18(1), 58-66.

Machfoedz, M. (1994). Financial Ratio Analysis and the Prediction of Earning Changes in Indonesia. In Kelola 1994 (Vol. 7, Issue 3, pp. 114-137).

Muzakki, M. R. (2015). Pengaruh Corporate Social Responsibility Dan Capital Intensity Terhadap Penghindaran Pajak. Pengaruh Corporate Social Responsibility Dan Capital Intensity Terhadap Penghindaran Pajak, 4(3), 445-452.

Okrayanti, T. Y., Utomo, S. W., \& Nuraina, E. (2017). Pengaruh Karakteristik Perusahaan Dan Corporate Governance Terhadap Tax Avoidance. Forum Ilmiah Pendidikan Akuntansi, 5(1), 804-817.

Pattiasina, V., Tammubua, M. H., Numberi, A., Patiran, A., \& Temalagi, S. (2019). Capital Intensity and tax avoidance: An Indonesian case. International Journal of Social Sciences and Humanities, 3(1), 58-71. https://doi.org/10.29332/ijssh.v3n1.250

Sekaran, U., \& Bougie, R. (2016). Research Methods for Business : a skill-building approach. Wiley (Seventh). West Sussex: John Wiley \& Sons.

Sparta, \& Handini, S. (2015). Pengaruh Kinerja Perusahaan dan Ukuran perusahaan Terhadap Keputusan Reklasifikasi Aset Keuangan Pada Perusahaan Perbankan Indonesia. Jurnal Keuangan Dan Perbankan, 12(1), 52-71.

Tandean, V. A., \& Winnie, W. (2016). The Effect of Good Corporate Governance on Tax Avoidance: An Empirical Study on Manufacturing Companies Listed in IDX period 2010-2013. Asian Journal of Accounting Research, 1(1), 28-38. https://doi.org/10.1108/ajar-2016-01-01-b004

Tirto. Id. (2019). DJP Dalami Dugaan Penghindaran Pajak Adora Energy. Diakses di https://tirto.id/djp-dalami-dugaan-penghindaran-pajak-pt-adaro-energyedKk

Widarjono, A. (2009). Ekonometrika Pengantar dan Aplikasinya (3rd ed.). Yogyakarta: Ekonisia.

Wiguna IPP, Jati IK. (2017). Pengaruh Corporate Social Responsibility, Preferensi Risiko Eksekutif, Dan Capital Intensity Pada Penghindaran Pajak. E-Jurnal Akuntansi. 21:418-446.

Wijayanti WP, Pratomo RA. (2016). Adaptation of Social-economic Livelihoods in Coastal Community: The Case of Mangunharjo Sub-District, Semarang City. Procedia - Socialand Behavioral Sciences. 227:477 484.doi:10.1016/j.sbspro.2016.06.103. 